\title{
The Relation of Metabolic Rate to Body Weight and Organ Size
}

\author{
A Review \\ M.A. Holliday ${ }^{[54]}$, D. Potter, A.Jarrah and S.Bearg \\ Department of Pediatrics, University of California, San Francisco Medical Center, San Francisco, California, \\ and the Children's Hospital Medical Center, Oakland, California, USA
}

Introduction

The relation of metabolic rate to body size has been a subject of continuing interest to physicians, especially pediatricians. It has been learned that many quantitative functions vary during growth in relation to metabolic rate, rather than body size. Examples of these are cardiac output, glomerular filtration rate, oxygen consumption and drug dose. This phenomenon may reflect a direct cause and effect relation or may be a fortuitous parallel between the relatively slower increase in metabolic rate compared to body size and the function in question.

The fact that a decrease in metabolism and many other measures of physiological function in relation to a unit of body size is observed in most biological systems. This phenomenon can be demonstrated by interspecies comparisons of mammals and birds, as well as within a species during growth or among matured members of a species that vary in size. Mice, for example, have a basal metabolic rate per $\mathrm{kg}(\mathrm{BMR} / \mathrm{kg})$ approximately thirteen times that of elephants. In the case of humans during growth, the infant has a BMR/kg more than twice that of the normal adult. A normal adult may have a BMR $/ \mathrm{kg}$ one and one-half times that of an obese adult.

The purpose of this paper is to review this subject and propose reasons why there is a lower $\mathrm{BMR} / \mathrm{kg}$ as body size increases. When applied to growing humans, the information developed should allow a greater precision in estimating BMR from body weight during growth. It will be seen that the factors responsible for the decline in BMR/kg during growth differ from the factors operative among different species. The equation describing the relation of $\mathrm{BMR}$ to body weight during growth also differs from the equation describing this relation among different species.

\section{Historical Background}

The measurement of metabolic rate was first achieved by LAvoisier in 1780. By 1839 enough measurements had been accumulated among subjects of different sizes that it was suggested in a paper read before the Royal Academy of France (co-authored by a professor of mathematics and a professor of medicine and science) that BMR did not increase as body weight increased but, rather, as surface area increased [42]. In 1889, Richet [38] observed that $\mathrm{BMR} / \mathrm{kg}$ in $\mathrm{rab}$ bits of varying size decreased as body weight increased; RUBNER [41] made a similar observation in dogs. Both noted that relating BMR to surface area provided results that did not vary significantly with size. These intraspecies observations were then extended to interspecies observations. In 1901, VoIT [48] observed that the BMR of 7 species of varying size ranged from 776 to 1089 calories $/ \mathrm{m}^{2}\left(\mathrm{cal} / \mathrm{m}^{2}\right.$ ) while the $\mathrm{BMR} / \mathrm{kg}$ varied from 11.3 to 75.1 calories $/ \mathrm{kg}$ ( $\mathrm{cal} / \mathrm{kg}$ ). He concluded that BMR varied as surface area varied. This relation came to be known as the 'surface area law'. To some, the 'surface area law' acquired the status of a fundamental biological principle [29]. Nonetheless, as technics improved, data were accumulated which ultimately challenged the 'surface area law'.

\section{Mathematical Models Relating BMR to Body Size}

In studying the differences among species, the BMR predicted for small animals from their surface area and the $\mathrm{BMR} / \mathrm{m}^{2}$ of larger animals was not as high as the observed rate. In 1932, KLEIBER [23] compared BMR to body weight of animals of 10 species which ranged from mouse to steer. He plotted the log of BMR as a function of the log of body weight. The relationship was expressed by the equation: $\mathrm{G}=71 \pm 1.8 \mathrm{~W} .75$ where 
$\mathrm{C}=\mathrm{BMR}$ in calories/day (cal/day) and $\mathrm{W}=$ weight body in $\mathrm{kg}$.

A similar relationship was described by BRODY and Procter [7] in the same year. In 1945, Brody [8] developed this relationship in great detail and summarized the data which related endogenous nitrogen and sulfur metabolism as well as BMR to the W.73. $\mathrm{K}_{\text {LEIBER }}{ }^{1}[24,25]$ confirmed his previous equation, using new data from animals of 16 species; his newly derived equation was $\mathrm{G}=69 \pm 1.5 \mathrm{~W}^{\cdot 75}$, which he simplified to $70 \times \mathrm{W} \cdot 75$. The fit was close for all the species studied, except for elephants and whales, where measurements were few and were difficult to obtain (fig. 1). The observed $\mathrm{BMR} / \mathrm{kg}$ in 5 examples selected from KLEIBER varied from 181 to $14.1 \mathrm{cal} / \mathrm{kg} /$ day but in each instance the observed value agreed with that predicted from his equation (table I). BRODY [8] published studies in birds in which the relation between body size and BMR was almost the same as that noted for mammals $\left(\mathrm{cal}=70 \times[\mathrm{kg}]^{.75}\right)$. The consistency of this relation over so wide a range of sizes and species suggests some unique biological advantage inherent within this relation. As size increases BMR increases less than weight but more than surface area.

In the meantime, an intensive search was being made for the best reference standard for BMR in adult humans, whose range in size was 5 to 10 -fold. GEPHART and DuBoIs [14] published standards for males from 20 to 50 years of age, of 'normal' stature, in which $90 \%$ fell within $\pm 15 \%$ of a standard value. HARris and Benedict [16] published an analysis of their data and derived a separate equation for men and women which took into account their height, weight and age. BootHBY and SANDIFORD [4] compared their results calculated from the empirical formulae of HARRIS and BENEDICT and from the surface area formula of DuBors [13] and found no greater variability in the data referred

Table I. BMR in adult mammals of various sizes (observed $\mathrm{cal} / \mathrm{kg} /$ day compared to predictions from Kleiber's formula : cal $=70 \times \mathrm{W} \cdot 75$ )

\begin{tabular}{lcccc}
\hline Species & $\begin{array}{l}\text { Body } \\
\text { weight } \\
(\mathrm{kg})\end{array}$ & $\begin{array}{l}\text { BMR } \\
\text { (cal/day) }\end{array}$ & $\begin{array}{l}\text { Cal/kg/day } \\
\text { Observed Predicted }\end{array}$ \\
\hline Mouse & 0.021 & 3.8 & 181 & 171 \\
Rat & 0.282 & 27 & 96 & 100 \\
Dog & 6.6 & 288 & 44 & 44 \\
Man & 55 & 1400 & 25 & 22 \\
Cow & 600 & 8460 & 15 & 13 \\
\hline
\end{tabular}

${ }^{1}$ The equation derived by Brody was $\mathrm{C}=70.5 \mathrm{~W}^{\cdot 734}$, which he rounded off to $\mathrm{G}=70.5 \mathrm{~W}^{\cdot 7}$, while KLEIBER preferred using W.75.

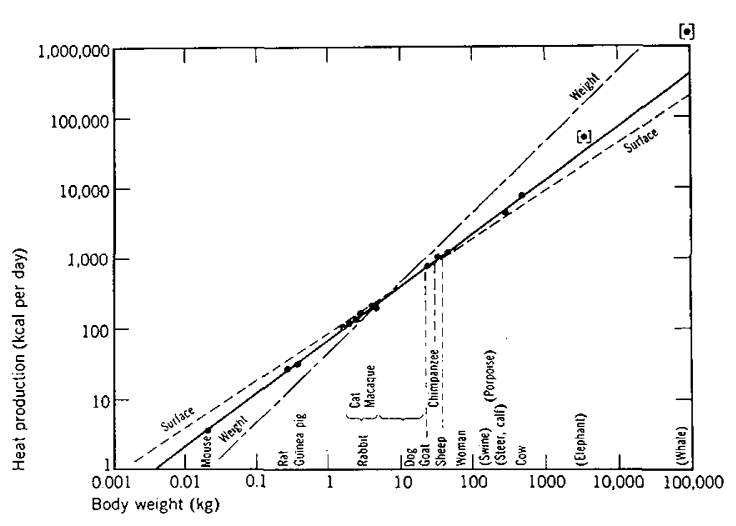

Fig. 1. Solid line (- - calculated regression equation of observed BMR and body weight. Hashed line (-_- ) theoretical line should BMR increase as a linear function of body weight, i.e. $\mathrm{BMR} / \mathrm{kg}=$ constant. Dashed line (--) theoretical line should BMR increase as a function of surface area or $W^{\cdot 67}$ (KLEIBER [24]).

to surface area than in the detailed formula of HARRIS and Benedict. More recently, Miller and Blyth [33] measured oxygen consumption in male college students (weight range 54 to $136 \mathrm{~kg}$ ) and found least variability when they related it tolean body mass, as opposed to surface area or weight. A still more recent study [50] observed the BMR to show the best degree of correlation with extracellular fluid volume. The difficulty in determining which function of size correlates with BMR among adult humans arises from the narrow range of size and BMR differences within this group, and the interdependence of the various functions of size to each other within the range.

The relation of BMR to body size during growth covers a wider range, so that correlations between $B M R$ and different variables of body size can be tested. Both Gephart and DuBois [14] and Benedict and TALBOT [2] noted that $\mathrm{BMR} / \mathrm{m}^{2}$ during growth differed significantly from that predicted from average adult values $/ \mathrm{m}^{2}$ (fig. 2 ). In newborn humans, the observed figures are lower; in the age group from 6 months to 3 to 4 years they are higher than those predicted; thereafter, they tend to approach the adult figure for $\mathrm{cal} / \mathrm{m}^{2} /$ day. A similar pattern of difference is noted in rats and in cattle during growth [8].

The standard values of BMR found by BENEDrCT and TALвот [2] and more recently by LEwis et al. [32] define an empiric and varying relation between BMR and body weight. An arithmetic plot of this relationship in boys, using the data of Benedict and TALBot, is illustrated in figure 3. The data for girls and the independent data of Lewis et al. [32] are not different in any important respects. 


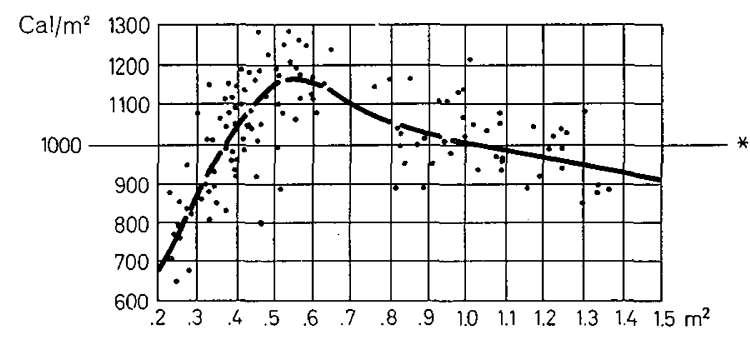

Fig. 2. Plot of $\mathrm{cal} / \mathrm{m}^{2}$ of observed data from normal children during growth. Below $0.3 \mathrm{~m}^{2}$ (3 mo age or $5 \mathrm{~kg}$ ), the observed figures are less than the adult averages; between $0.3 \mathrm{~m}^{2}$ and $0.6 \mathrm{~m}^{2}$ (6 months to $3-4$ years) the observed data are higher than predicted from adult averages (from GEPHART and DuBors [14] and Benedict and TAlBot [2]).

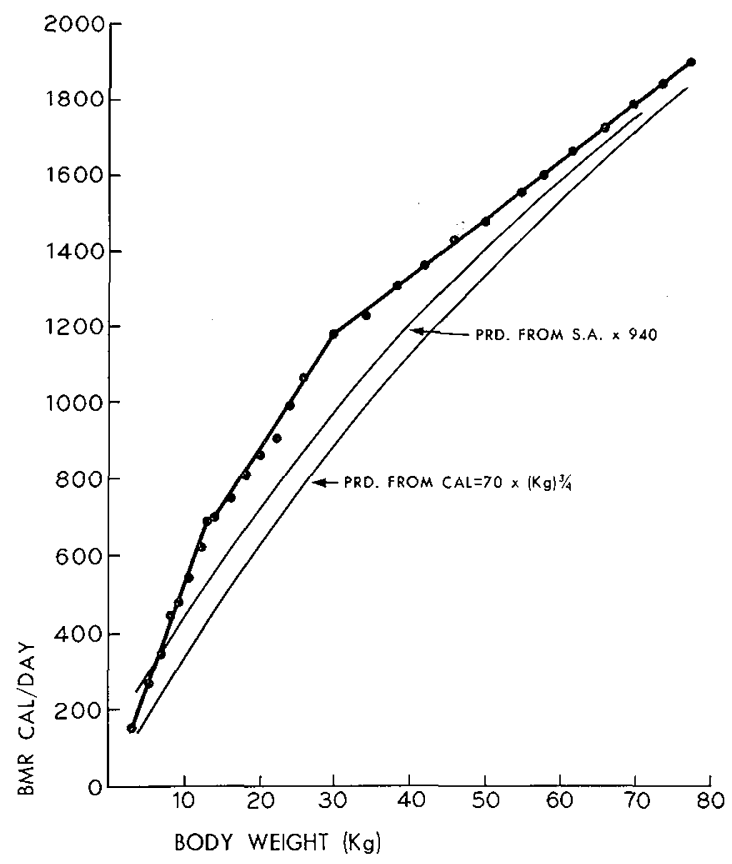

Fig. 3. Heavy line describes observed relation between body weight and BMR (from data of BENEDICT and Tацвот [2]). Upper light line describes relation between body weight and BMR should BMR vary as a linear function of surface area. Lower light line describes this relation should BMR vary as a linear function of $\mathrm{W}^{.75}$.

This plot can be described by 3 successive straight lines with changing slopes. From $3 \mathrm{~kg}$ (birth) to 10 to $12 \mathrm{~kg}$ (approximately 18 months), the slope represents a $55 \mathrm{cal} / \mathrm{kg}$ increase. From approximately $12 \mathrm{~kg}$ to $28 \mathrm{~kg}$, the average increase is $30 \mathrm{cal} / \mathrm{kg}$. From $28-30$ to $80 \mathrm{~kg}$ the increase in BMR is $15 \mathrm{cal} / \mathrm{kg}$. For comparison, the predicted BMR from the adult rate $/ \mathrm{m}^{2}$ surface area, using standard surface area figures for weight, and the BMR predicted from KLEIBER's formula: $\mathrm{G}=70 \times \mathrm{W} .75$ are plotted. The predictions, using either theoretical relation, come close to the observed figures at points in infancy and again at maturity, but with considerable differences at other points.

The highest BMR/kg in humans during growth is 56 calories at $6 \mathrm{~kg}$; the lowest is 25.5 calories at $70 \mathrm{~kg}$ body weight. The rate of 'increase' of BMR and of body weight are compared in figure 4 by plotting the log of BMR as a function of the log of body weight. Their comparative rates of growth are constant and equal up to $10-12 \mathrm{~kg}$ - the plot is linear and the slope is 1.0 . Beyond 10-12 kg the rate of 'increase' of BMR is much slower than that of body weight (slope 0.58 ) but the comparative rate of 'increase' over this range is relatively constant. For comparison, lines are drawn describing the theoretical rate of increase in BMR with growth, assuming it is a linear function of surface area and of body weight to the 0.75 power. Each of these theoretical curves deviates significantly from the curve of the observed values. From the curve of observed data it is evident that the rate of 'increase' of BMR in relation to body weight changes at $10-12 \mathrm{~kg}$. At $30-38 \mathrm{~kg}$ a second, less obvious, change can be seen which is more evident in the arithmetic plot (fig.3). In humans, the comparative rates of increase of weight and BMR do not conform precisely either to the surface area or to any other simple function of body size over the total range.

The difficulty in applying mathematical models to the relation of BMR to body weight is evident from the foregoing discussion. A simple mathematical description of the relation could be found only in interspecies models which encompass an enormous range of sizes. When a model was sought relating BMR to body size in humans, either among different-sized adults or during growth, no simple mathematical model could be found. It then seemed appropriate to formulate a new question: What is the source of BMR? In attempting to answer this question a second question (how BMR might vary in relation to body size) could be reduced to simple alternatives that lent themselves to testing. The rest of this review centers on 3 postulates and the evidence we have adduced in their support.

Postulate 1. Most of the BMR of an organism is derived from the metabolic activity of the principal internal organs; i.e., brain, liver, lungs, heart and kidneys.

It has been observed that the internal organs have an organ metabolic rate per gm $(\mathrm{OMR} / \mathrm{g})$ that is much higher than that of the body as a whole and that much of the total BMR is derived from the metabolic rate of 


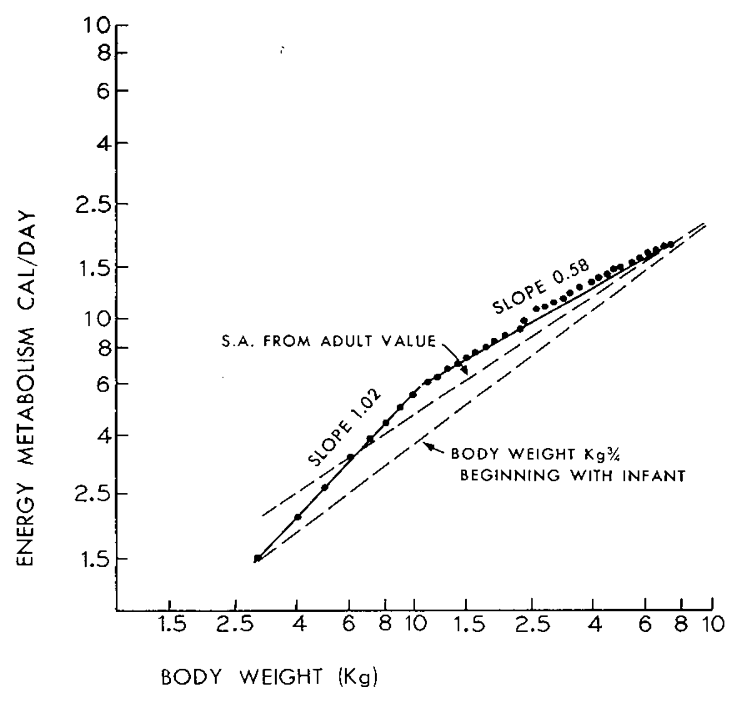

Fig.4. Data used in figure 3 plotted on $\log$ - $\log$ coordinates compares the rates of growth of BMR to body weight. By definition, both of the theoretical curves are linear in a log-log plot. Slope of S.A. line is 0.67 ; of W.75 is 0.75 .

the internal organs. A direct test of this in normal adult humans can be approached from measurements of oxygen consumption and mass of specific organ systems and summating these for comparison with the total BMR. We have estimated the percent of total BMR derived from five organs, four of which have been measured directly and one, the lung, for which a figure had to be calculated indirectly. This has been possible since KETY [21] developed a technic for measuring organ oxygen utilization and organ size in intact living subjects, so that a figure $\left(\mathrm{ml} \mathrm{O}_{2} / 100 \mathrm{~g}\right.$ organ-brain in this case) could be derived. In normal man, the oxygen utilization by brain was found to be $3.7 \mathrm{ml} /$ $100 \mathrm{~g} / \mathrm{min}, 260 \mathrm{cal} / \mathrm{kg} /$ day or assuming $4.9 \mathrm{cal} / \mathrm{L} / \mathrm{O}_{2}$. Applying the same technic to the kidney, CrosLex et al. [11] reported that renal oxygen consumption in young male adults was $5.5 \mathrm{ml} / 100 \mathrm{~g}$ kidney/min or 400 $\mathrm{cal} / \mathrm{kg} /$ day. Liver oxygen consumption has had to be derived from splanchnic oxygen consumption. The best figures vary between $3.5-4.8 \mathrm{ml} / 100 \mathrm{~g} / \mathrm{min}$ or 350 $\mathrm{cal} / \mathrm{kg} /$ day [6]. For the heart, oxygen consumption in normal man is $8.6 \mathrm{cal} / 100 \mathrm{~g}$ left ventricle/min or $600 \mathrm{cal} / \mathrm{kg} / \mathrm{day}$ [39]. For comparison, the BMR of the whole body is $25 \mathrm{cal} / \mathrm{kg} /$ day in adults and $56 \mathrm{cal} / \mathrm{kg} /$ day in infants. There are no data on oxygen consumption of intact lungs. However, the $\mathrm{QO}_{2}$ of lung, as measured in a Warburg respirometer, is somewhat less than that of liver.
On the assumption that lung metabolic activity is proportional to its $\mathrm{QO}_{2}$ in vitro, we have calculated (table II) the calorie contributions from these 5 organs, $\mathrm{OMR} / \mathrm{g}$ and total $\mathrm{OMR}$, in a $70 \mathrm{~kg}$ adult and compared them with BMR. Assuming that OMR/g of each organ is the same in childhood (Postulate 3), a similar calculation can be made for a $10 \mathrm{~kg}$ infant; $79 \%$ of the BMR can thus be derived from these 5 organs in the adult and $79 \%$ in the $10 \mathrm{~kg}$ infant. The balance comes, of course, from muscle and lesser amounts from the smaller organs, the supportive structures and fat. However, it seems likely that with reasonable allowance for error, from $70-80 \%$ of BMR in adults is derived from organs which comprise $7 \%$ of body weight; a similar percent of BMR in children is derived from these organs which comprise $15 \%$ of body weight. Aschoff, as cited by Sмгтн [1], derived the following figures of OMR as percent of BMR: splanchnic and visceral organs $37.3 \%$; brain $17.8 \%$; heart $11.9 \%$; kidney $4.9 \%$; for a total of $80.5 \%$.

The precision of these calculations is open to some question until measurements are made of regional oxygen consumption of more organs and of extremities at rest, and until these measurements are extended to children and other species of varying sizes. However, the magnitude of error in the available data would appear to be small. The OMR/kg brain, heart, kidney and liver are all approximately 10-20 times the figure for the body as a whole, $25 \mathrm{cal} / \mathrm{kg}$, so that much of the body must have a correspondingly lower metabolic rate. The figures leave surprisingly little to muscle as a source of metabolic activity in the basal state. Measurement of oxygen consumption in intact resting muscle has not been achieved, although Aschoff [1] estimated only $17.4 \%$ of total BMR to be derived from muscle. Muscle is a prime source of extra heat in the event of cold stress, or physical activity. However, its relative unimportance as a source of basal metabolic energy is suggested by the fact that $B M R / k g$ body weight decreases with growth, while muscle mass $/ \mathrm{kg}$ body weight increases.

Further evidence in support of this view may be adduced from the observation on BMR during recovery from starvation [34]. BMR/kg actual body weight is below normal in children with protein depletion (kwashiorkor) and within normal range in children with calorie deprivation as a result of starvation (marasmus). During recovery from malnutrition, the BMR rises to levels substantially above normal within days in both groups, and before there is any major increase in the depleted muscle mass. As muscle mass increases, $\mathrm{BMR} / \mathrm{kg}$ of whole body begins to decrease toward normal. It has been suggested that the low and normal $\mathrm{BMR} / \mathrm{kg}$ reflect a depression of tissue metabolic activity due to the effects of starvation and depression of 
Table II. Organ metabolic rate, OMR, cal/day compared to whole body BMR for a $10 \mathrm{~kg}$ infant and a $70 \mathrm{~kg}$ adult

\begin{tabular}{|c|c|c|c|c|c|c|c|c|}
\hline \multirow[t]{3}{*}{ Organ } & \multicolumn{4}{|c|}{$10 \mathrm{~kg}$ infant } & \multicolumn{4}{|c|}{$70 \mathrm{~kg}$ adult } \\
\hline & \multirow[t]{2}{*}{$\begin{array}{l}\text { OMR/kg } \\
\text { (cal/kg/day) }\end{array}$} & \multirow[t]{2}{*}{$\begin{array}{l}\text { Weight } \\
(\mathrm{kg})\end{array}$} & \multicolumn{2}{|c|}{$\begin{array}{l}\text { OMR } \\
\mathrm{cal} / \text { organ/day }\end{array}$} & \multirow[t]{2}{*}{$\begin{array}{l}\mathrm{OMR} / \mathrm{kg} \\
\text { (cal/kg/day) }\end{array}$} & \multirow[t]{2}{*}{$\begin{array}{l}\text { Weight } \\
(\mathrm{kg})\end{array}$} & \multicolumn{2}{|c|}{$\begin{array}{l}\text { OMR } \\
\text { cal/organ/day }\end{array}$} \\
\hline & & & total & $\%$ & & & total & $\%$ \\
\hline Brain [21] & 260 & .92 & 240 & 45 & 260 & 1.4 & 365 & 21 \\
\hline Heart [39] & 600 & .05 & 30 & 6 & 600 & .3 & 180 & 10 \\
\hline Kidney [11] & 400 & .07 & 28 & 5 & 400 & .3 & 120 & 7 \\
\hline Liver (splanchnic) [6] & 350 & .30 & 105 & 19 & 350 & 1.6 & 560 & 32 \\
\hline Lung (estimated) & (200) & 12 & 24 & 4 & (200) & .8 & 160 & 9 \\
\hline \multicolumn{2}{|c|}{ Total derived from 5 organs } & 1.46 & 427 & 79 & & 4.4 & 1385 & 79 \\
\hline Total BMR & & & 540 & & & & 1780 & \\
\hline
\end{tabular}

thyroid function. The high $\mathrm{BMR} / \mathrm{kg}$ during repair has been ascribed to normal tissue metabolic activity and the disproportionate percentage of body weight taken up by the metabolically active brain.

We would suggest that the high BMR was due, in part, to the relatively high proportion of body weight taken up by all the internal organs, including the brain -not that they are large, but that supporting structures are disproportionately small.

To the extent that BMR is predominantly a result of the sum of OMR, the factors which lead to a reduction of BMR $/ \mathrm{kg}$ as body size increases can be examined from the size and OMR/g of the internal organs during growth. For the reasons already suggested, it is proper to examine the differences separately among species of different sizes and within a species during growth.

Postulate 2. The lower BMR/kg in larger species is due to 2 factors: the source of metabolic energy-the highly active organs-constitutes a smaller percent of total body weight in larger animals; and some of the highly active organs, e.g., liver and kidney, have lower $O M R / g$ as animal size increases.

Neither factor has a systematic influence in determining a combined effect, yet this combined effect is a remarkably consistent function of body size predicted by the equation $\mathrm{G}=70 \times \mathrm{W}^{\cdot 75}$. The 5 examples selected from the 16 species in figure 1 illustrate the variations in $\mathrm{BMR} / \mathrm{kg}$ that exist and the precision of KLEIBER's formula for predicting the BMR of any individual group in the sample (table $\mathrm{I}$ ). The BMR ranges from 181 to $14 \mathrm{cal} / \mathrm{kg}$, indicating that the mouse has a BMR 13 times that of the steer. The prediction of total metabolic activity from KLEIBER's equation is very close to the observed values. If the decline of $\mathrm{BMR} / \mathrm{kg}$ during growth is due solely to a decreasing ratio of highly active organs to total body weight, the log-log plot of the weight of the organs against body weight should be linear and have a slope of 0.75 . The ratio of the highly active organs to body weight in a steer would then be $1 / 13$ that found in the mouse. The OMR/g should not vary among the species. On the other hand, if the ratio of the highly active organs to body weight was constant, irrespective of body size, a log-log plot of the sum of organs' weight against body weight should be linear, with a slope of 1.0 and the $\mathrm{OMR} / \mathrm{g}$ in the steer would be $1 / 13$ that of the mouse. In this case, the decrease in $\mathrm{BMR} / \mathrm{kg}$ would be due only to a decrease in the $\mathrm{OMR} / \mathrm{g}$ as the size of the animal increases ${ }^{2}$.

The actual relation of organ weight to body weight for 9 species is compared in table III. In figure 5, the data are plotted on a log-log graph together with lines describing the two extreme alternatives. The actual data lie between these lines in random distribution, indicating that differences in relative weight of highly active organs account for some but not all the differences in $\mathrm{BMR} / \mathrm{kg}$ observed among different species. Organ weight increases at a rate slower than body weight as animals get bigger, but more rapidly than metabolic activity. No consistent pattern of decrease is observed. If the organs are the principal source of metabolic energy, then it is necessary to conclude that $\mathrm{OMR} / \mathrm{g}$ is less in larger species but not as much less as $\mathrm{BMR} / \mathrm{kg}$ body weight.

As noted, there are few studies which provide data in the intact state for comparing the OMR/g of animals of various sizes. The renal oxygen consumption for dog kidney is $125 \mu \mathrm{l} / \mathrm{g}$ wet kidney/min [47] and

2 The decrease which would fit the requirements of this relation is defined by cal $/ \mathrm{g}$ decreasing to the -0.25 power of unit weight as weight increases. 
that for man is $55 \mu \mathrm{l} / \mathrm{g}$ wet kidney/min [11]. An analysis of hepatic oxygen consumption in several species demonstrated that the consumption increased at a rate only slightly greater than metabolic rate, i.e., OMR/g liver decreased in a manner nearly parallel to the $\mathrm{BMR} / \mathrm{kg}[6]$.

The problem of making comparisons of the BMR of homologous tissue from animals of different species therefore has been approached by measuring the tissue oxygen consumption $\left(\mathrm{QO}_{2}\right)$ of these tissues and assuming that $\mathrm{QO}_{2}$ mirrors the oxygen consumption of the tissues in the intact resting state. Terrolne and Roche [46] and GRAFE et al. [15] found that the $\mathrm{QO}_{2}$ of homologous organs declined as animal size increased, but the decline was proportionately less than the $\mathrm{BMR} / \mathrm{kg}$. They concluded that change in tissue BMR/ $\mathrm{g}$ was not responsible for the difference in $\mathrm{BMR} / \mathrm{kg}$. KLeIber [26] on the other hand, noted that the $\mathrm{QO}_{2}$ of liver was lower in animals of larger size and that these differences, projected to the body as a whole, would account for the lower $B M R / \mathrm{kg}$.

KREBS [27], who studied 5 tissues from animals of 9 different species, found a decrease in $\mathrm{QO}_{2}$ for homologous organs as the animals increased in size and their $\mathrm{BMR} / \mathrm{kg}$ decreased. However, the decrease among different species for a given organ was generally less than the decrease in BMR/kg. Among the organs tested, the $\mathrm{QO}_{2}$ of liver decreased the most as a function of body size, although less than BMR/kg. KREBS concluded from his studies that changes in OMR/g could not account wholly for the decline in $\mathrm{BMR} / \mathrm{kg}$ and postulated that changes in muscle metabolism must occur concomitantly. He discounted, as unproven, the earlier statements of KESTNER [20] and BLANK [3] that lower $\mathrm{BMR} / \mathrm{kg}$ in larger animals could be explained altogether by a decrease in the proportions of total body weight as highly active organs. The evidence upon which KESTNER made these statements was considered by $\mathrm{K}_{\mathrm{REBS}}$ as insufficient to support their claims. It seems to us, however, that their data and the data in table III and figure 5 suggest this to be a factor in the decline, although not the only one.

Davies [12] recently reviewed the relation between $\mathrm{QO}_{2}$ and body metabolism and plotted all of KREBS' data for $\mathrm{QO}_{2}$ against body weight on log-log coordinates. The slope of decline in $\mathrm{QO}_{2}$ of the various organs was less than the decrease in BMR/kg, but a significant negative slope was observed for most organs. There were considerable differences in the slopes among the 9 organs studied.

In a study reported previously [18], we demonstrated that glomerular filtration rate (GFR)/g kidney in the rat $(1.17 \mathrm{ml} / \mathrm{g})$ was larger than that in dogs $(0.65$ $\mathrm{ml} / \mathrm{g}$ ) which, in turn, was larger than that in humans $(0.45 \mathrm{ml} / \mathrm{g})$. GFR has been shown to vary directly with

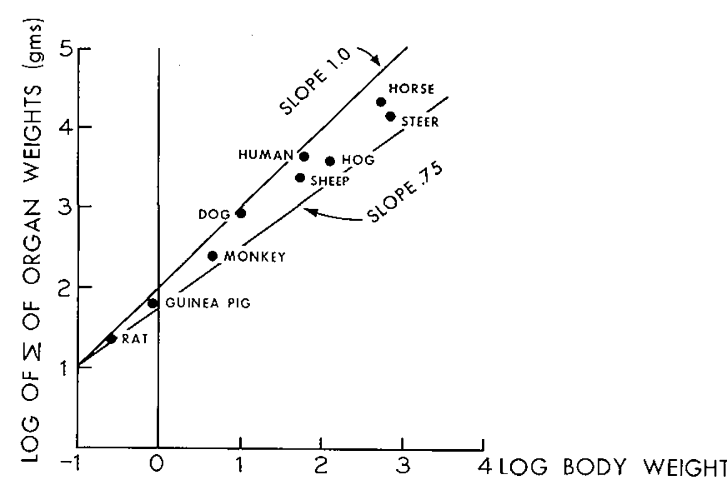

Fig.5. Log-log plot of the sum of the organs noted in table III plotted against body weight. The line with a slope of 1.0 illustrates the theoretical curve which defines a growth pattern in which internal organs are a constant per cent of total body weight. The line with a slope of 0.75 illustrates the theoretical curve of organ growth if it corresponded to the relation of BMR to body weight among animals of different species. The actual data lie between these 2 curves.

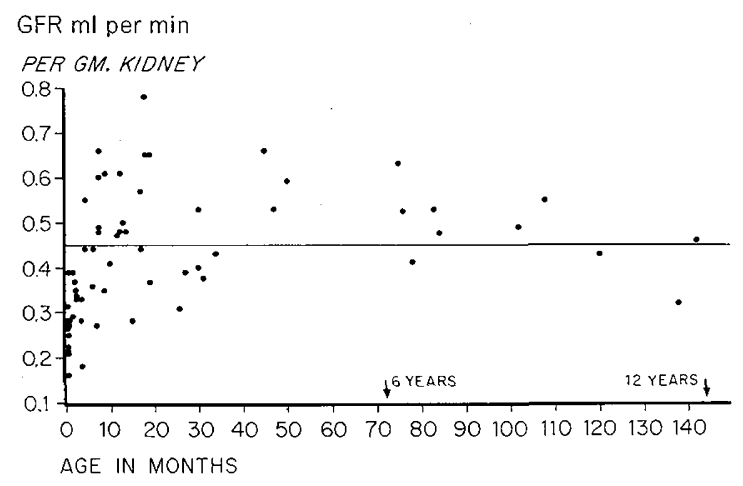

Fig.6. A plot of GFR/g kidney, using data of GFR and kidney weight derived from body weight to arrive at the value GFR/g kidney (from HoluIDAY and EGAN [18]).

renal oxygen consumption [31]. These differences correspond to the differences in $\mathrm{BMR} / \mathrm{kg}$ characteristic of these species (table I-rat 96; dog 44; man $25 \mathrm{cal} / \mathrm{kg}$ ).

When all the observations are considered together, it seems that $\mathrm{OMR} / \mathrm{g}$ in the same organs among different species decreases as body size increases although the pattern varies for different organ systems. The sum of the effects of these decreases in OMR/g appears to be less on the average than the observed decrease in the BMR $/ \mathrm{kg}$ in the body. From these figures and those on organ weight as percent of body weight (table III, figure 5), we have arrived at the conclusion that a relative decrease in weight of the highly active organs as percent of body weight and a decrease in OMR/g are 
The relation of metabolic rate to body weight and organ size

Table III. Relation of organ weight to body weight in 9 species (Data from BRoDy [8])

\begin{tabular}{|c|c|c|c|c|c|c|c|c|c|}
\hline Organ & Dog & $\begin{array}{l}\text { Guinea } \\
\text { pig }\end{array}$ & Hog & Horse & Human & Monkey & Rat & Sheep & Steer \\
\hline \multicolumn{10}{|c|}{ Organ weight $(\mathrm{g})$} \\
\hline Brain & 175 & 4.7 & 120 & 670 & 1300 & 42 & 2.00 & 105 & 500 \\
\hline Heart & 85 & 2.3 & 350 & 4250 & 320 & 23 & 0.94 & 280 & 2300 \\
\hline Kidneys & 140 & 11.2 & 500 & 3320 & 500 & 42 & 4.20 & 320 & 2000 \\
\hline Liver & 420 & 27.0 & 1600 & 6700 & 1700 & 110 & 12.00 & 960 & 5000 \\
\hline Lung & 120 & 5.0 & 1300 & 5400 & 980 & 30 & 1.30 & 710 & 3900 \\
\hline \multirow[t]{3}{*}{ Total } & 940 & 50.2 & 3890 & 20,340 & 4800 & 247 & 20.44 & 2375 & 13,700 \\
\hline & \multicolumn{9}{|c|}{ Body weight $(\mathrm{kg})$} \\
\hline & 10 & 0.8 & 125 & 600 & 60 & 4.5 & 0.25 & 52 & 700 \\
\hline \multirow{2}{*}{\multicolumn{10}{|c|}{$\frac{\text { Sum of total organ wt }}{\text { body weight }}$}} \\
\hline & & & & & & & & & \\
\hline & 9.44 & 6.25 & 3.12 & 3.39 & 8.0 & 5.49 & 8.16 & 4.56 & 1.95 \\
\hline
\end{tabular}

Table IV. Relation of $\mathrm{QO}_{2}$ of kidney to body weight and of GFR/g kidney weight to body weight during growth in rats (PotTer et al. [37]).

\begin{tabular}{|c|c|c|c|c|c|c|c|}
\hline \multicolumn{3}{|c|}{ Group $\mathrm{A}^{1}$} & \multicolumn{5}{|c|}{ Group $\mathrm{B}^{2}$} \\
\hline $\begin{array}{l}\text { No. of } \\
\text { animals }\end{array}$ & $\begin{array}{l}\text { Body weight } \\
\text { (g) }\end{array}$ & $\mathrm{QO}_{2}{ }^{3}$ & $\begin{array}{l}\text { No. of } \\
\text { animals }\end{array}$ & $\begin{array}{l}\text { Body weight } \\
\text { (g) }\end{array}$ & $\begin{array}{l}\text { Kidney } \\
\text { weight (g) }\end{array}$ & $\begin{array}{l}\text { GFR } \\
(\mathrm{ml} / \mathrm{min})\end{array}$ & $\begin{array}{l}\text { GFR/g } \\
\text { kidney } \\
\text { weight }\end{array}$ \\
\hline 10 & 58 & 12.6 & 8 & 60 & 0.65 & 0.65 & 1.03 \\
\hline 10 & 110 & 13.9 & 11 & 115 & 1.09 & 1.48 & 1.36 \\
\hline 10 & 204 & 14.3 & 8 & 198 & 1.69 & 2.61 & 1.54 \\
\hline 10 & 320 & 16.7 & 17 & 338 & 2.26 & 3.10 & 1.37 \\
\hline 10 & 397 & 14.7 & 12 & 389 & 2.62 & 3.48 & 1.33 \\
\hline
\end{tabular}

${ }^{1}$ Group A: Normal growing rats sacrificed at observed weights to obtain $\mathrm{QO}_{2}, \mathrm{DNA}$, protein and water content of kidney.

${ }^{2}$ Group B: Normal growing rats in which GFR was measured as inulin clearance and related to kidney weight obtained following the clearance.

${ }^{3} \mathrm{QO}_{2}$ measured in a Warburg respirometer as $\mu \mathrm{l}$ of $\mathrm{O}_{2} / \mathrm{mg}$ dry wt/hr. in kidney cortical slices incubated in a buffered Ringer solution at $37^{\circ} \mathrm{C}$.

responsible for the decline in $\mathrm{BMR} / \mathrm{kg}$ observed among species as body size increases.

Postulate 3. Decrease in BMR/kg during growth is due to a relatively slower growth of the highly active organs, compared to total body weight; OMR/g organ does not appear to decrease during growth.

Since most of BMR has its source in the internal organs and $\mathrm{BMR} / \mathrm{kg}$ in humans declines during growth from 56 to $25 \mathrm{cal} / \mathrm{kg}$ and in rats from 218 to $87 \mathrm{cal} / \mathrm{kg}$, it is appropriate to examine the role of these organs in this decline. The decline, as seen among different species, may be due either to a decrease in the $\mathrm{OMR} / \mathrm{g}$ or to a decrease in the relative organ weight in relation to body weight, or both.

OMR/g during growth has been studied in 2 ways: by $\mathrm{QO}_{2}$ and by indirect measurement of kidney metabolism in the intact organism. In both, the OMR/g did not decrease during growth but remained constant, or increased slightly. The $\mathrm{QO}_{2}$ of several organs of rats was measured at different intervals of growth by von Bertalanffy and Pirozynski [49], who found the $\mathrm{QO}_{2}$ to be constant. Mourex [35], who measured the $\mathrm{QO}_{2}$ of rat brain in newborns and during 


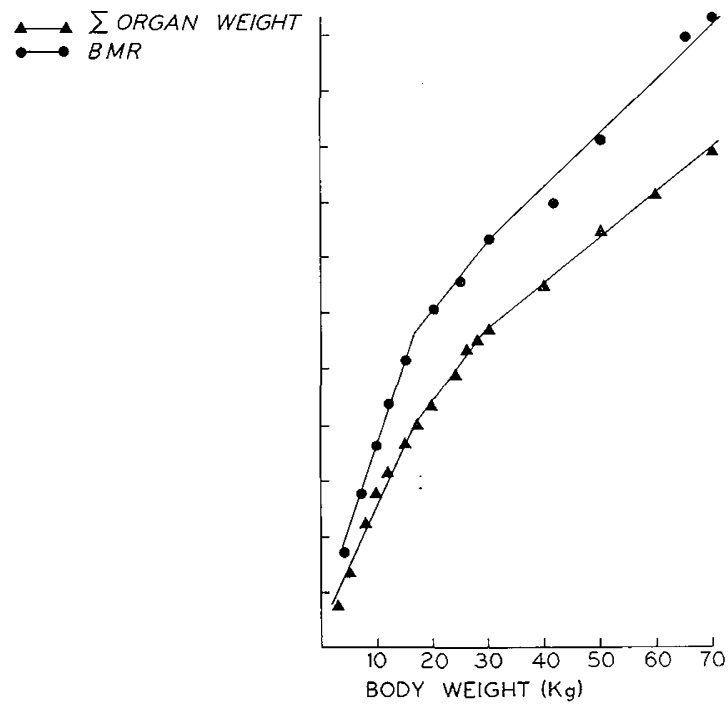

Fig.7. Plot of BMR against body weight using the same data as in figure 3 and the sum of organs (table III) against body weight (data for organ weight from Boyd [5] and Coppoletta and Wohlbach [10]). Arbitrary units were chosen for the ordinate to permit comparison of curve slopes.

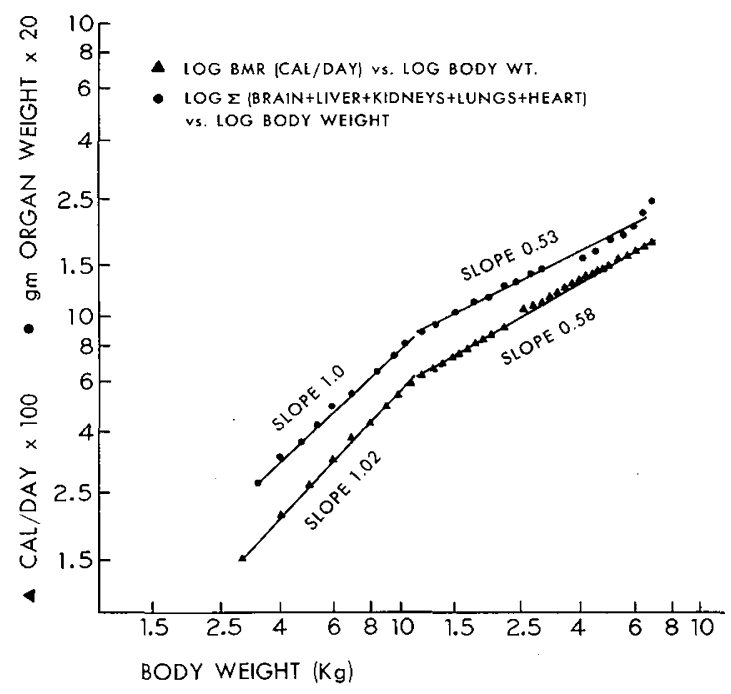

Fig.8. A log-log plot of the data to allow for a comparison in rate of 'increase'. There is an obvious parallel between the comparative rates of 'increase' of BMR to body weight and of the internal organs to body weight. growth, found some increase during the neonatal period but no significant change later. NEw et al. [36] measured the $\mathrm{QO}_{2}$ of kidney slices of rabbits and found no increase after the neonatal period. These findings differ from those cited earlier in comparing $\mathrm{QO}_{2}$ of organs from species of different sizes (Postulate 2).

In a study from our own laboratory, $\mathrm{QO}_{2}$ of rat kidney was measured at 5 successive periods of growth from 50 to $400 \mathrm{~g}$ body weight) and no decrease was noted [37] (table IV, group A). Similarly, we found the $\mathrm{QO}_{2}$ of liver slices in $60 \mathrm{~g}$ rats did not differ from that of $350 \mathrm{~g}$ rats. From these data we inferred that $\mathrm{OMR} / \mathrm{g}$ as measured by $\mathrm{QO}_{2}$ did not decrease in response to growth as organ size increased. We also measured GFR of rats at successive ages. GFR is a quantitative measure of sodium reabsorption which has been noted to be a direct function of oxygen consumption in the kidney in the intact state [31]. These data are illustrated in table IV, group B. The GFR/g kidney increased as the rat grew from 60 to $115 \mathrm{~g}$ but thereafter was stable and did not decrease. The GFR was measured during growth in humans and related to body weight, kidney weight and surface area $[40$, 22]. The GFR/g kidney did not appear to vary during growth after 6 months of age (fig. 6 ).

These findings differ from those among different species where GFR/g kidney varied inversely as a function of body size [18]. We infer from these findings and the $\mathrm{QO}_{2}$ data that $\mathrm{OMR} / \mathrm{g}$ does not decrease during growth as body size increases in either rats or humans. If this is the case, then the pattern of change in BMR to body weight during growth should be the same as the pattern of change in weight of the internal organs to body weight.

The plots of BMR to body weight and organ weight to body weight in humans during growth are noted in figure 7. The rates of growth using log-log plots are compared in figure 8 . The patterns are quite similar: as body weight increases from 3 to $10-12 \mathrm{~kg}, \mathrm{BMR}$ and weight of internal organs increase at the same rate (slopes 1.02 and 1.0, respectively). Thereafter, both organ weight and BMR increase at a slower rate than body weight (slope averages 0.53 for organ weight and 0.58 for BMR). This indicates that upward from 10-12 $\mathrm{kg}, \mathrm{BMR} / \mathrm{kg}$ declines during growth because its principal source (the internal organs) becomes a smaller proportion of body weight as growth progresses.

These observations thus provide a rational basis for the varying relationship of BMR to body weight during growth. The pattern is similar to that proposed earlier for estimating average metabolic rate of hospitalized patients as a means for determining parenteral fluid requirements $[19,22]$ and illustrates the reason for the deviation during growth of $\mathrm{cal} / \mathrm{m}^{2}$ from the average adult value. 


\section{Discussion}

It has been the purpose of this review to suggest the means by which $\mathrm{BMR} / \mathrm{kg}$ decreases as body weight increases. This decrease, by whatever means, has the biological advantage of diminishing heat production as the surface to volume ratio decreases. The factors responsible for this in different species vary. During growth within a species the principal factor is the slower rate of growth of high heat-producing organs as compared to supporting structures.

Muscle is generally considered to be the greatest source of heat or metabolic activity in the body. It is certainly the largest heat-producing organ and is the greatest potential source when the animal or human is subjected to cold or work stress. Yet the evidence presented would suggest that muscle is not a principal source of heat production in the resting state. Its relative unimportance as a source for basal metabolic energy is evident in the growth pattern, either in humans [43] or rats [9]. In both, muscle mass is $25 \%$ of body weight shortly after birth, when BMR/kg is high; in adults it is $40 \%$ of body weight or 1.7 times that in infancy. The BMR $/ \mathrm{kg}$ in the adult is 0.5 that of the human infant and 0.4 that of the young rat.

The growth rate data of the individual organs and surface area, plotted against body weight using log-log coordinates (fig.7), suggest some of the complexities that face the physician who treats a growing child. The proper reference standard for drug dosage may be related more appropriately to organ size or function rather than to body weight or surface area. Some of the problems have been solved empirically, but this method may be hazardous as medicine begins to deal with anephric patients or increasingly small premature infants with very different body compositions. It is hoped that an extension of these observations will produce a more precise tool for predicting potential metabolic function and for estimating drug dosage as a function of age and size. In the past, part of the difficulty in defining the relations of metabolic rate to body size might have been avoided if the distinction had been made between inter- and intraspecies, mature animals within a species of different size and composition, and growing animals with a characteristic change in composition during growth. Surface area is a better reference standard for $\mathrm{BMR}$ than body weight among different species covering a wide range in body size, but an even better reference standard is body weight to the 0.75 power.

It is not surprising that Kleiber's formula (cal = $70[\mathrm{~W}]^{.75}$, which was the best fit for a range of weights from 0.022 to $4000 \mathrm{~kg}$, is not equally precise when applied to humans during the growth from 3.5 to $70 \mathrm{~kg}$. Some of the special reasons for this have been admirably summarized by BRoDy [8]. The unknown but evident biological advantage in the specific relation of BMR to body weight, which is defined by Kleiber's formula in animals over a weight range of nearly 200,000-fold, need not apply so rigorously within the 20 -fold weight span encompassed by human growth. The mathematics have a different order of magnitude.

The point is perhaps most clearly made from the observations relating oxygen consumption to body size in infants. Sinclarr and Silverman [44] observed that oxygen consumption $/ \mathrm{kg}$ increased as body size increased in infants varying in weight from 1 to $3 \mathrm{~kg}$. They further observed that the oxygen consumption $/ \mathrm{kg}$ was higher in 'small for dates' babies than in premature infants of equal size. They concluded that metabolic mass in this period of growth was increasing more rapidly than body size, probably due to the relative loss of extracellular fluid. Sinclarr, Scopes and Silverman [45] more recently demonstrated that 'resting oxygen consumption rate was found to be rather constantly related to body cell mass', which in turn was increasing relatively faster than body size. BMR $/ \mathrm{kg}$ in this group varied less than $\mathrm{BMR} / \mathrm{m}^{2}$ or $\mathrm{BMR} / \mathrm{kg} \cdot{ }^{7}$ but $\mathrm{BMR} / \mathrm{kg}$ active cell mass (including fat) varied least.

The central role of the internal organs as compared to muscle in determining BMR has suggested to us that some purpose may be served by considering cell mass as consisting of two relatively distinct moieties, organs and muscle. These have different growth rates and distinct metabolic rates. The effect of body composition on BMR may be suggested from a recent study [30] in which children with acyanotic congenital heart disease were found to have a high $\mathrm{BMR} / \mathrm{kg}$ compared to normal children of the same age. These authors described the finding as an example of hypermetabolism. An alternative explanation, suggested from these studies, is that these children had relatively poor growth, particularly of muscle and supporting structures; consequently, the internal organs which have a high OMR comprised a relatively larger percent of body weight. These higher rates would account in part for a higher $\mathrm{BMR} / \mathrm{kg}$ total body weight. In infants during recovery from growth failure of various causes [28], BMR when related to height or to ideal weight for height was normal, but was high when related to observed weight, i. e., BMR $/ \mathrm{kg}$. Since the actual weight, not height or ideal weight, was generating the metabolic rate, its observed high value can be related to a difference in body composition, rather than to a difference in cell metabolism. A similar observation [34] in infants recovering from starvation has been cited ( $\mathrm{cf}$. part 2). A much more obvious example is found in obesity [17] in which a measure of the size of internal organs, as a reference standard for BMR, would be an interesting test of the hypothesis that BMRis different in obese people. 
In concluding, we feel that BMR during normal growth is best fitted to the empiric curve of observed data in relation to body size than to either surface area or W.75. Perhaps a more important suggestion from these studies, is the need to relate BMR to a measure of internal organ mass when it is abnormal and use this reference as a test of whether basal metabolic rate is altered at the cellular level or simply is a reflection of an altered ratio of internal organ mass to total body size. Such a separation may be valuable in studies of disease states associated with malnutrition and in the study of premature and 'small for dates' infants where assessment of energy metabolism is the central issue.

\section{References and Notes}

1. Aschoff, J.: in Smith, R.E. and Hoyer, D.J.: Metabolism and cellular function in cold acclimation. Physiol. Rev. 42: 60 (1962).

2. Benedict, F.G. and Talbot, F.B.: Metabolism and growth from birth to puberty, Carnegie Inst. Wash. Pub. 302 (1921).

3. Blank, H.: Tiergröße und Stoffwechsel. Pflüg. Arch. ges. Physiol. 234: 310 (1934).

4. Boоthby, W.M. and SAndiford, I.: Summary of basal metabolism data on 8,614 subjects with special reference to normal standards for estimating basal metabolic rate. J. biol. Chem. 54: 783 (1922).

5. Boyd, E. : Outline of physical growth and development (Burgess, Minnesota 1942).

6. Brauer, R.W.: Liver circulation and function. Physiol.Rev. 43: 115 (1963).

7. Brody, S. and Procter, R. C.: Growth and development with special reference to domestic animals. XXIII. Relation between basal metabolism and mature body weight in different species of mammals. Univ. Mo.Agr. Exp.Sta. Res. Bull. 166: 89 (1932).

8. BRODY, S.: Bioenergetics and growth, with special reference to the efficiency complex in domestic animals (Reinhold, New York 1945).

9. Cheek, D.B.; Powell, G.K. and Scott, R.E.: Growth of muscle mass to skeletal collagen in the rat. I. Normal growth. Johns Hopk. Hosp. Bull. 116: 378 (1965).

10. Coppoletta, J.M. and Wolbach, S.B.: Body length and organ weights of infants and children, study of body length and normal weights of more important vital organs of body between birth and 12 years of age. Amer. J. Path. 9: 55 (1933).

11. Grosley, A.P.; Castillo, C. and Rowe, G. G.: The relationship of renal oxygen consumption to renal function and weight in individuals with normal and diseased kidneys. J.clin. Invest. 40: 836 (1961).
12. Davies, M.: On body size and tissue respiration J.cell. comp. Physiol. 57: 135 (1961).

13. DuBors, F. and DuBors, E.F.: The measurement of the surface area of man. Arch. intern. Med. 15: 868 (1915).

14. Gephart, F. G. and DuBois, E. G.: Clinical calorimetry. X. The determination of the basal metabolism of normal men and the effect of food. Arch. intern. Med. 15: 835 (1915).

15. Grafe, E.; Reinwein, H. und Singer, V.: Studien über Gewebsatmung. II. Die Atmung der überlebenden Warmblüterorgane. Biochem. Z. 165: 102 (1935).

16. Harris, J.A. and Benedict, F.G.: A biometric study of human basal metabolism in man (Carnegie Inst., Wash. Pub. 279, 1919).

17. Heald, F.P.: Basal oxygen consumption in the obese adolescent. J. Pediat. 61: 327 (1962).

18. Holliday, M.A. and Egan, T.J.: Renal function in man, dog and rat. Nature (Lond.) 193: 748 (1962).

19. Holliday, M.A. and Segar, W.E.: Maintenance need for water in parenteral fluid therapy. Pediatrics 19: 823 (1957).

20. Kestner, O.: Metabolism and size of organs. J. Physiol. 87: 39 (1936).

21. Kety, S.S. and Schmidt, C.F.: Nitrous oxide method for quantitative determination of cerebral blood flow in man: theory, procedure and normal values. J. clin. Invest. 27: 476 (1948).

22. Kleeman, C.R. and Maxwell, M.H.: Disorders of fluid and electrolyte metabolism (MaGraw Hill, New York 1962).

23. Kleiber, M.: Body size and metabolism. Hilgardia 6: 315 (1932)

24. Kletber, M.: Body size and metabolic rate. Physiol. Rev. 27: 511 (1947).

25. Kleiber, M.: The fire of life, an introduction to animal energetics (John Wiley and Sons, New York 1961,).

26. Kleiber, M.: Body size and metabolism of liver slices in vitro. Proc. Soc. exp. Biol. (N.Y.) 48: 419 (1941).

27. Krebs, H.A.: Body size and tissue respiration. Biochem. Biophys. Acta 4: 249 (1950).

28. KrIEger, I.: The energy metabolism in infants with growth failure due to maternal deprivation, undernutrition or causes unknown. Metabolic rate calculated from the insensible loss of weight. Pediatrics 38: 63 (1966).

29. LEE, M. O.: Determination of surface area of white rats with its application to expression of metabolic results. Amer.J. Physiol. 89: 24 (1929).

30. Lees, M.H.; Bristow, J.D. ; Griswold, H. E. and Olmsted, R. W.: Relative hypermetabolism in in- 
fants with congenital heart disease and undernutrition. Pediatrics 36: 183 (1965).

31. Lassen, N.A.; Munck, O. and Thaysen, J.H.: Oxygen consumption and sodium reabsorption in the kidney, Acta physiol.scand. 51: 371 (1961).

32. Lewis, R. G.; Duval, A. M. and Iliff, A.: Standards for basal metabolism of children from 2 to 15 years of age, inclusive. J. Pediat. 23: 1 (1943).

33. Mrller, A.T., Jr. and Blyth, C.S.: Lean body mass as a metabolic reference standard. J.appl. Physiol. 5: 311 (1953).

34. Montgomery, R.D.: Changes in the basal metabolic rate of the malnourished infant and their relation to body composition. J.clin. Invest. 41: 1653 (1963).

35. Mourex, J.: The effect of glucose and age on the in vitro oxygen consumption of the rat brain. Physiol. bohemoslov. 14: 79 (1965).

36. New, M.; McNamara, H. and Kretchmer, N.: Accumulation of para-aminohippurate by slices of kidney from rabbits of various ages. Proc. Soc. exp. Biol. (N.Y.) 102: 558 (1959).

37. Potter, D.; Sakai, T.; Jarrah, A.; Bearg, S.; Mates, J. : Harrah, J. and Hollmday, M.A.: The relation of kidney function to kidney size during growth in rats (in preparation).

38. Rrahet, G.: La chaleur animale. Bibliothèque Scientifique Internationale (Felix Alcan, Paris 1889).

39. Rowe, G.G.; Gastillo, G.A.; Maxwell, G.M. and CRumpton, G.W.: Comparison of systemic and coronary hemodynamics in the normal human male and female, Circulat. Res. 7: 728 (1959).

40. Rubin, M.; BRUGK, E. and RAPOPORT, M.: Maturation of renal function in childhood, clearance studies. J. clin. Invest. 28: 1144 (1949).

41. Rubner, M.: in Krogh, A.: The respiratory exchange of animals and man, p. 133 (Longmans, New York 1916).

42. Sarrus et Rameaux: Mémoire adressé a l'Académie Royale. Bull. Acad. roy. Méd. Belg. 3: 1094
(1839); in Kleiber, M. : Fire of life (John Wiley and Sons, New York 1961).

43. Sнонц, A.T.: Mineral metabolism. Monograph series No. 82 (Reinhold New York 1939).,

44. Sinclarr, J. and Silverman, W.A.: Intrauterine growth in active tissue mass of the human fetus, with particular reference to the undergrown baby. Pediatrics 38: 48 (1966).

45. Sinclair, J. C.; Scopes, J.W. and Silverman, W. A.: Metabolic reference standards for the neonate. J.Pediat. 69: 910 (1966).

46. Terroine, E.F. et Roche, J.: Production calorique et respiration des tissus in vitro chez des homeothermes. Acad.Sci.compt.rend. 180: 225 (1925).

47. Thurau, K.: Renal Na-reabsorption and $\mathrm{O}_{2-}$ uptake in dogs during hypoxia and hydrochlorothiazide infusion. Proc. Soc. exp. Biol. (N.Y.) 106: 714 (1961).

48. Vorr, E. : Über die Grösse des Energiebedarfes der Tiere im Hungerzustande. Z. Biol. 23: 113 (1901).

49. Von Bertalanffy, L. and Prrozynski, J.: Tissue respiration and body size. Science 113: 599 (1951).

50. Wedgwood, R.J.; Nass, D.E.; Klimas, J.A.; Kleeman, C. R. and Quinn, M.: Relationship of body composition to basal metabolic rate of normal man. J.appl. Physiol. 6: 317 (1953).

51. Supported by the following Grants: National Institutes of Health Training Grant 1-TI-HD-182-01 and Research Grant AM 11316-01, as well as General Support Grant 5-No.1-FR5467-02.

52. Supported by San Joaquin County Heart Association, at Children's Hospital Medical Center, Oakland, Cal.

53. The authors wish to express their gratitude to Miss Jean Harrah for valuable assistance and to Mrs. Anne Schmid and Suzanne Holliday for valuable manuscript assistance.

54. Hollidax, M.A., M. D., Department of Pediatrics, University of California, San Francisco Medical Center, San Francisco, Cal. 94122 (USA). 